
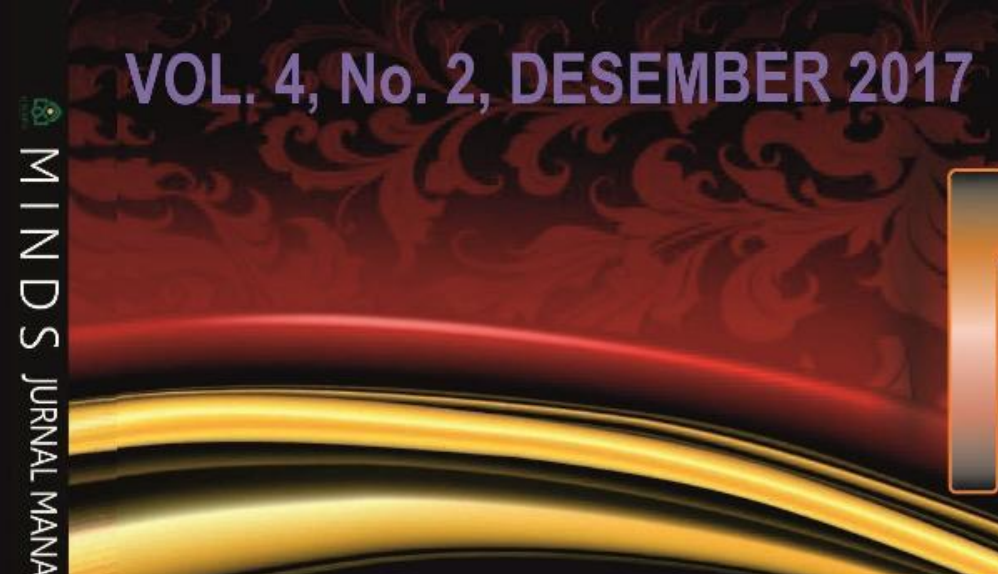

ShI

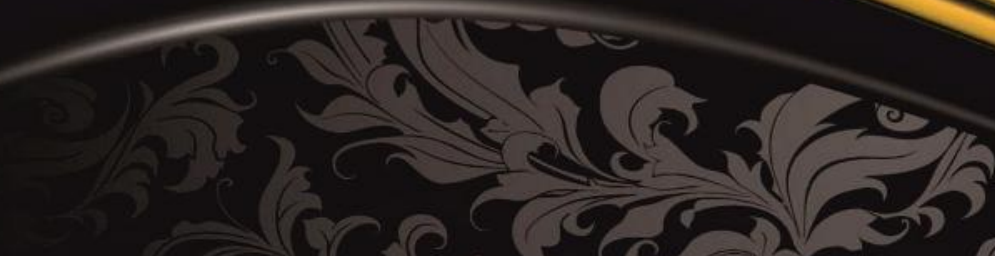

(ब)
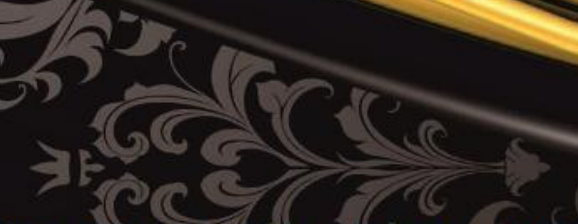

(C)

IDENTIFIKASI GAYA KEPEMIMPINAN PADA ORGANISASI RELAWAN PENANGGULANGAN BENCANA DI JAWA TIMUR

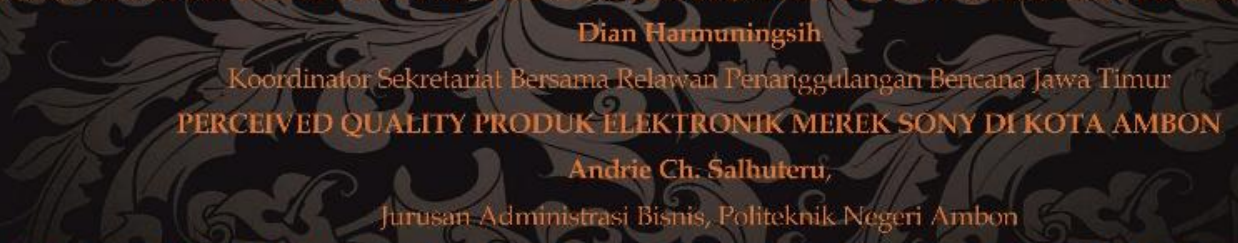

PENGARUH PROFITABILITAS, UIKUIDITAS, LEVERAGE, DAN FIRM SIZE TERHADAP KEBIJAKAN DIVIDEN PERUSAHAAN

$$
\begin{aligned}
& \text { DI INDEKS JII, PERIODE 2011-2015 } \\
& \text { Rika Dwi Ayu Parmitasari \& Hasrianto, }
\end{aligned}
$$

Jurusan Manajemen Fakultas Ekonomi dan Bisnis Islam, UIN Alauddin Makassar

FAKTOR YANG MEMENGARUHI KEPUASAN NASABAH BANK MUAMALAT CABANG AMBON

$$
\text { Gilman Pary, }
$$

Institut Agama Islam Negeri Ambon,

PENGARUH ATRIBUT PRODUK DAN PERILAKU PENCARIAN VARIASI TERHADAP PERILAKU MAHASISWA BERPINDAH MEREK PONSEL PADA FAKULTAS EKONOMI DAN BISNIS ISLAM Jusmiati \& Ahmad Efendi,

Jurusan Manajemen, Fakultas Ekonomi dan Bisnis Islam, UIN Alauddin Makassar

PENGARUH KUALITAS LAYANAN TERHADAP KEPUASAN PELANGGAN RUTE DOMESTIK GARUDA INDONESIA DI KOTA AMBON Saul Ronald Jacob Saleky,

Jurusan Administrasi Bisnis, Politeknik Negeri Ambon

PENGARUH STRES KERJA DAN IKLIM ORGANISASI TERHADAP TURNOVER KARYAWAN

$$
\text { Ludy Sapulette, }
$$

Jurusan Administrasi Bisnis, Politeknik Negeri Ambon

PENGARUH PEMBERDAYAAN DAN BUDAYA ORGANISASI TERHADAP PROFESIONALISME DOSEN

Ady Andardinata,

STIE Tri Dharma Nusantara

PENGARUH CSR, FIRM SIZE DAN INTEREST-BASED DEBT TERHADAP NILAI PERUSAHAAN PADA PERUSAHAAN MANUFAKTUR DI INDEKS JII, PERIODE 2010-2016

Wahidah Abdullah, Alim Syariati, \& Reskianti hamid

Fakultas Ekonomi dan Bisnis Islam, UNN Alauddin Makassar

ANALISIS DIMENSI KUALITAS PELAYANAN TERHADAP KEPUASAAN PASIEN PADA RSUD SYEKH YUSUF SUNGGUMINASA Asdi,

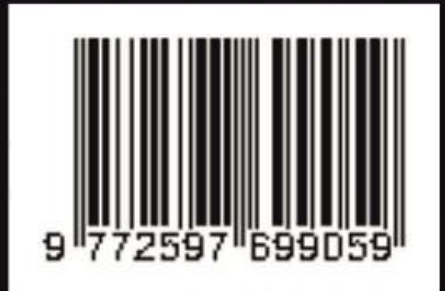

FEB, Lniversitas Muhammadiyah Makassar 
[Type text]

\section{KATA PENGANTAR}

Assalamualaikum WR. WB.

Puja dan puji syukur mari kita panjatkan ke hadirat Allah SWT, karena atas berkah dan karunia-Nya, maka Jurnal Manajemen dan Inspirasi (MINDS), Jurusan Manajemen, Fakultas Ekonomi dan Bisnis Islam, UIN Alauddin Makassar ini dapat diselesaikan. Salam dan shalawat kita haturkan kepada Nabi Muhammad SAW, sang pelita di tengah kejumudan dan kejahiliyahan, serta sumber informasi dan inspirasi yang terpercaya, al-Amiin. Terima kasih kami sampaikan kepada seluruh pihak yang terlibat dalam penyusunan jurnal Minds dari awal hingga akhir yang tidak dapat kami sebutkan satu persatu.

Adapun jurnal Minds merupakan titik kulminasi perwujudan kemampuan menulis tenaga pendidik yang berada di intra Fakultas maupun luar universitas. Tulisan akademik yang diharapkan menjadi contoh nyata jawaban dari berbagai fenomena empiris yang relevan dari sisi keilmuan Manajemen. Edisi kali ini, yaitu Vol. 4, No.2, 2017, mengupayakan adanya pengembangan dari sisi kualitas tulisan maupun sebaran wilayah penulis. Upaya ini diharapkan akan mendorong terciptanya proses yang lebih terukur baik dari penulis, mitra bestari, maupun penyunting, sehingga peningkatan kualitas publikasi ilmiah dapat diharapkan sebagai keluaran yang pasti.

Seiring dengan penerbitan jurnal ini, maka mewakili tim publikasi, saya menyampaikan rasa terima kasih yang sebesar-besarnya untuk seluruh penulis yang berpartisipasi dalam edisi kali ini, dan kepada para pembaca yang telah berkenan meluangkan waktunya untuk menelaah tulisan-tulisan yang termuat pada edisi kali ini.

Wassalamualaikum WR.WB.

Manajer Jurnal,

Dr. Alim Syariati, SE., M.Si. 


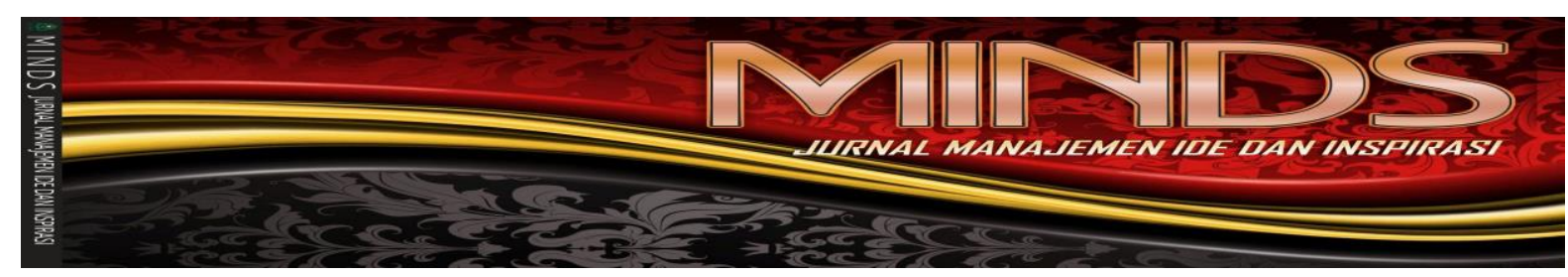

\section{DAFTAR ISI}

IDENTIFIKASI GAYA KEPEMIMPINAN PADA ORGANISASI

RELAWAN PENANGGULANGAN BENCANA DI JAWA TIMUR......

Dian Harmuningsih

Koordinator Sekretariat Bersama Relawan Penanggulangan Bencana Jawa Timur

PERCEIVED QUALITY PRODUK ELEKTRONIK MEREK SONY

DI KOTA AMBON

Andrie Ch. Salhuteru,

Jurusan Administrasi Bisnis, Politeknik Negeri Ambon

PENGARUH PROFITABILITAS, LIKUIDITAS, LEVERAGE, DAN

UKURAN PERUSAHAAN TERHADAP KEBIJAKAN DIVIDEN

SAHAM-SAHAM YANG TERDAFTAR PADA

JAKARTA ISLAMIC INDEX (JII) PERIODE TAHUN 2011-2015........

Rika Dwi Ayu Parmitasari \& Hasrianto,

Jurusan Manajemen Fakultas Ekonomi dan Bisnis Islam, UIN Alauddin Makassar

FAKTOR YANG MEMENGARUHI KEPUASAN NASABAH

BANK MUAMALAT CABANG AMBON

Gilman Pary,

Institut Agama Islam Negeri Ambon,

PENGARUH ATRIBUT PRODUK DAN PERILAKU PENCARIAN

VARIASI TERHADAP PERILAKU MAHASISWA BERPINDAH MEREK

PONSEL PADA FAKULTAS EKONOMI DAN BISNIS ISLAM............

Jusmiati \& Ahmad Efendi,

Jurusan Manajemen, Fakultas Ekonomi dan Bisnis Islam, UIN Alauddin Makassar

PENGARUH KUALITAS LAYANAN TERHADAP KEPUASAN PELANGGAN RUTE DOMESTIK GARUDA INDONESIA DI KOTA AMBON

Saul Ronald Jacob Saleky,

Jurusan Administrasi Bisnis, Politeknik Negeri Ambon

PENGARUH STRES KERJA DAN IKLIM ORGANISASI TERHADAP

TURNOVER INTENTION

Ludy Sapulette,

Jurusan Administrasi Bisnis, Politeknik Negeri Ambon

PENGARUH PEMBERDAYAAN DAN BUDAYA ORGANISASI

TERHADAP PROFESIONALISME DOSEN.

Ady Andardinata,

STIE Tri Dharma Nusantara 
PENGARUH CORPORATE SOCIAL RESPONSIBILITY (CSR), UKURAN PERUSAHAAN DAN INTEREST BASED DEBT (IBD) TERHADAP NILAI PERUSAHAAN PADA PERUSAHAAN MANUFAKTUR (YANG TERDAFTAR DI JAKARTA ISLAMIC INDEX PERIODE 2010-2016)..... Wahidah Abdullah, Alim Syariati, \& Reskianti hamid

Fakultas Ekonomi dan Bisnis Islam, UIN Alauddin Makassar

ANALISIS DIMENSI KUALITAS PELAYANAN TERHADAP KEPUASAAN PASIEN PADA RSUD SYEKH YUSUF SUNGGUMINASA

Asdi, FEB,

Universitas Muhammadiyah Makassar 


\title{
FAKTOR YANG MEMENGARUHI KEPUASAN NASABAH BANK MUAMALAT CABANG AMBON
}

\author{
Gilman Pary*
}

\begin{abstract}
ABSTRAK
Tujuan penelitian ini untuk menguji pengaruh faktor atribut produk Islam, komitmen agama, kepercayaan, dan kualitas layanan terhadap kepuasan nasabah, baik secara parsial maupun secara simultan pada Bank Muamalat Cabang Ambon. Nasabah yang dimaksud adalah nasabah Bank Muamalat Cabang Ambon baik sebagai penitip dana maupun pengguna dana yang telah menggunakan jasa bank Muamalat Cabang Ambon minimal satu tahun. Sampel penelitian ini adalah 73 orang nasabah Bank Muamalat Cabang Ambon, yang diambil dengan metode aksidental, yaitu penentuan sampel berdasarkan kebetulan, siapa saja yang secara kebetulan bertemu dengan peneliti pada saat pengumpulan data dapat digunakan sebagai sampel. Teknik analisis data menggunakan regresi linier berganda. Hasil penelitian menunjukan atribut produk, komitmen agama, kualitas jasa dan kepercayaan secara bersama-sama berpengaruh positif dan signifikan terhadap kepuasan nasabah Bank Muamalat Cabang Ambon. Atribut produk, komitmen agama, kualitas jasa dan kepercayaan mampu menjelaskan loyalitas nasabah baik secara simultan maupun parsial.
\end{abstract}

Kata kunci: atribut produk Islam, komitmen agama, kepercayaan, kualitas layanan, kepuasan nasabah

\begin{abstract}
The purpose of this study is to examine the influence of attribute factors of Islamic products, religious commitment, trust, and quality of service on customer satisfaction, either partially or simultaneously at Bank Muamalat Ambon Branch. The customer in question is the customer of Muamalat Bank Ambon Branch either as a cash custodian or a fund user who has used the services of Bank Muamalat Ambon Branch at least one year. The sample of this research is 73 customers of Bank Muamalat Branch of Ambon, taken by accidental method, that is the determination of sample by chance, anyone who by chance meet with the researcher at the time of data collection can be used as sample. Data analysis techniques use multiple linear regression. The research results show product attributes, religious commitment, service quality and trust together have a positive and significant impact on customer satisfaction of Bank Muamalat Ambon Branch. Product attributes, religious commitment, service quality and trust are able to explain customer loyalty either simultaneously or partially.
\end{abstract}

\footnotetext{
* Institut Agama Islam Negeri Ambon, Jln. Air Kuning, Batu Merah: (parygilman@gmail.com)
} 
Keywords: attributes of Islamic products, religious commitment, trust, service quality, customer satisfaction

\section{PENDAHULUAN}

Keberadaan perbankan syariah sebagai salah suatu lembaga keuangan di Indonesia merupakan sesuatu yang tak terhindarkan. Dengan komposisi penduduk yang sebagian besar memeluk agama Islam, Indonesia merupakan pasar yang menjanjikan bagi sistem perbankan yang menggunakan nilai-nilai agama dalam pengembangan usahanya. Dukungan kebijakan pemerintah dan regulasi moneter Bank Indonesia telah memberi ruang gerak yang lebih luas bagi pelaku bisnis perbankan syariah.

Bank syariah yang memiliki filosofi utama kemitraan dan kebersamaan (sharing) dalam profit dan risk diharapkan dapat mengakomodasi kebutuhan masyarakat terhadap layanan jasa perbankan yang sesuai dengan prinsip syariah. Dalam operasionalnya, perbankan syariah memiliki nilai yang tidak dapat tersaingi sistem konvensional yaitu digunakannya standar moral islami dalam kegiatan usahanya. Azas keadilan dan kemanfaatan bagi seluruh umat mampu mendorong terciptanya sinergi yang sangat bermanfaat bagi bank dan nasabahnya. Selain itu, penerapan prinsip bagi hasil dalam kegiatan perbankan syariah juga akan menumbuhkan rasa tanggungjawab pada masing-masing pihak, baik bank maupun debiturnya.

Kehadiran perbankan syariah dimulai dengan berdirinya Bank Muamalat Indonesia pada tahun 1992. Kini telah ada Bank Syariah Mandiri, Bank BNI Syariah, Bank Syariah Mega, BRI Syariah, Bank CIMB Niaga Syariah. Bank syariah merupakan bank yang beroperasi sesuai dengan prinsip-prinsip syariah Islam. Artinya bank yang beroperasi mengikuti ketentuan-ketentuan syariah Islam khususnya menyangkut tata cara bermuamalat secara Islam. Persaingan sektor perbankan yang ketat membuat bank syariah perlu melakukan perbaikan strategi usahanya, antara lain melalui peningkatan pelayanan yang dapat memuaskan nasabah (Syariati, 2012a,b).

Sejak kehadirannya hingga saat ini masih banyak kendala yang dihadapi dalam pengembangan perbankan syariah yaitu: (1) Pemahaman masyarakat yang belum tepat terhadap kegiatan operasional bank syariah, (2) Peraturan perbankan yang belum sepenuhnya mengakomodasi operasional bank syariah, (3) Jaringan kantor bank syariah yang belum luas, (4) Sumber daya manusia yang memiliki keahlian dalam bank syariah masih sedikit (Antonio, 2001).

Kepuasan nasabah merupakan salah satu faktor penentu dalam menunjang keberhasilan usaha bank syariah. Kotler (2001) mengatakan bahwa tugas perusahaan adalah menciptakan pelanggan. Untuk mampu mendapatkan kepercayaan dari pelanggan, perusahaan harus menerapkan konsep pemasaran yang berorientasi kepada pelanggan dan menekankan bahwa pembeli adalah raja yang harus dilayani dan terpuaskan (Kotler, 2001).

Kepuasan nasabah merupakan sebuah perbandingan dari apa yang diharapkan pelanggan dengan apa yang diterima nasabah. Apabila yang didapatkan oleh nasabah melebihi harapannya maka nasabah tersebut dapat meraih kepuasan, dan sebaliknya apabila harapan nasabah lebih tinggi dari 
yang didapatkan maka nasabah tersebut belum terpuaskan. Dalam hal ini bank syariah harus mampu meningkatkan kepuasan tersebut sehingga nasabah tidak beralih kepada bank lain untuk memenuhi kebutuhannya.

Peningkatan kualitas pelayanan yang diberikan oleh bank syariah dapat dijadikan kebijakan untuk keberhasilan bisnis di dunia perbankan pada saat ini maupun masa yang akan datang. Pelayanan pada nasabah suatu bank, mencakup faktor-faktor yang secara tradisional mewarnai penilaian nasabah atas layanan yang diterima, seperti kecepatan, ketepatan, keramahan dan kenyamanan. Kualitas pelayanan memiliki pengaruh yang signifikan terhadap kepuasan pelanggan (Churchil and Suprenant, 1982; Singh and Kaur, 2011; Barat and Spillan, 2012; Saleky, et. al, 2014a, 2014b, 2015, 2016; Salhuteru, 2017). Di samping kualitas pelayanan, terdapat faktor atribut-atribut produk yang bernuansa Islami yang ditawarkan oleh bank, kepercayaan serta komitmen agama, yang memiliki pengaruh terhadap kepuasan pelanggan.

Berdasarkan latar belakang masalah di atas, penelitian ini dilakukan dengan judul "Faktor yang Memengaruhi Kepuasan Nasabah PT Bank Muamalat Cabang Ambon", dengan pertanyaan penelitian yang diajukan sebagai berikut :

1. Apakah terdapat pengaruh atribut produk terhadap kepuasan nasabah Bank Muamalat Cabang Ambon.

2. Apakah terdapat pengaruh komitmen agama terhadap kepuasan nasabah Bank Muamalat Cabang Ambon.

3. Apakah terdapat pengaruh kepercayaan terhadap kepuasan nasabah Bank Muamalat Cabang Ambon.

4. Apakah terdapat pengaruh kualitas layanan terhadap kepuasan nasabah Bank Muamalat Cabang Ambon.

5. Apakah terdapat pengaruh simultan atribut produk Islam, komitmen agama, kepercayaan dan kualitas layanan terhadap kepuasan nasabah Bank Muamalat Cabang Ambon.

Penelitian ini bertujuan untuk menganalisis pengaruh faktor atribut produk Islam, komiten agama, kepercayaan, dan kualitas layanan terhadap kepuasan nasabah Bank Muamalat Cabang Ambon, baik secara simultan maupun parsial.

Hasil penelitian ini dapat memberi masukan bagi pihak manajemen PT Bank Muamalat dalam mendesain strategi pemasaran yang lebih baik sebagai usaha peningkatan kepuasan bagi nasabahnya.

\section{LANDASAN TEORITIS}

Bak Syariah dan Produknya

Bank syariah secara harfiah dapat diartikan sebagai bank Islam atau bank sesuai syariah atau bank yang operasional sesuai dengan prinsip-prinsip syariah. Bank syariah adalah bank yang beroperasi sesuai dengan prinsipprinsip syariah Islam, yaitu mengacu kepada ketentuan-ketentuan yang ada dalam Alquran dan Hadis" (Kuncoro dan Suhardjono, 2002). Prinsip syariah adalah aturan perjanjian berdasarkan hukum Islam antara bank dengan pihak lain untuk penyimpanan dana dan atau pembiayaan kegiatan usaha atau kegiatan lainnya yang sesuai dengan syariah. 
Bank syariah memiliki karakteristik umum dan menjadi landasan operasional bank syariah secara keseluruhan yaitu prinsip bagi hasil (profit sharing). Secara syariah, prinsipnya berdasarkan kaidah mudharabah. Berdasarkan prinsip ini, bank syariah akan berfungsi sebagai mitra, baik dengan penabung maupun dengan pengusaha yang memeroleh pembiayaan. Meskipun demikian, dalam perkembangannya, para pengguna dana bank syariah tidak saja membatasai dirinya pada satu akad, yaitu mudarabah saja. Sesuai dengan jenis dan natur usahanya, mereka akan memeroleh dana dengan sistem perkongsian, sistem jual beli, sewa menyewa, dan lain-lain. Oleh karena itu, hubungan bank syariah dengan nasabahnya menjadi sangat kompleks karena tidak hanya berurusan dengan satu akad, akan tetapi dengan berbagai jenis akad.

Sebagai lembaga bisnis, bank syariah tetap harus memiliki daya tarik ekonomi. Namun pertimbangan ekonomi bukan merupakan pertimbangan yang mendasar. Hal lain yang lebih penting yaitu moral. Karena itu produkproduk yang diberikan bank syariah tidak pernah lepas dari aturan syariah. Selalu ada pertimbangan yang bersifat $u k h r a w i$, yaitu pertimbangan halal dan haram.

Sistem perbankan syariah berbeda dengan sistem perbankan konvensional karena sistem keuangan dan perbankan syariah adalah subsistem dari suatu sistem ekonomi Islam yang cakupannya lebih luas. Prinsip utama yang dianut oleh bank syariah antara lain larangan bunga dalam berbagai transaksi, menjalankan bisnis dan aktivitas perdagangan yang berbasis pada memeroleh keuntungan yang sah menurut syariah, dan menumbuh-kembangkan zakat.

Produk yang ditawarkan oleh perbankan syariah dapat dibagi menjadi tiga bagian, yaitu penyaluran dana (financing), penghimpunan dana (funding), dan jasa (service) (Karim, 2010). Penghimpunan dana di bank syariah berbentuk giro, tabungan dan deposito. Prinsip operasional syariah yang diterapkan dalam pengimpunan dana masyarakat adalah prinsip wadiah dan mudharabah (Karim, 2010). Dalam menyalurkan dana kepada nasabah, secara garis besar terdapat empat kelompok prinsip operasional syariah, yaitu prinsip jual beli (bai'), sewa beli (ijarah wa iqtina), bagi hasil (syirkah) dan pembiayaan lainnya" (Siamat, 2004; Karim, 2010).

\section{Atribut Produk}

Produk mempunyai arti yang penting bagi konsumen. Karena itu dalam membeli produk, konsumen biasanya melihat pada atribut yang dimiliki oleh produk tersebut. Atribut produk itu meliputi mutu (kualitas), merek, kemasan, harga dan pelayanan produk (Stanton, 1996). Kualitas produk adalah kemampuan suatu produk untuk melakukan fungsi-fungsinya; kemampuan itu meliputi daya tahan, kehandalan, ketelitian yang dihasilkan, kemudahan dioperasikan dan diperbaiki, dan atribut lain yang berharga pada produk secara keseluruhan. Kualitas dari setiap produk yang dihasilkan merupakan salah satu unsur yang harus mendapat perhatian yang sungguh-sungguh dari perusahaan kalau perusahaan ingin memenangkan suatu persaingan dalam industri tertentu (Angipora, 1999). 
Mutu diukur bukan dari sudut kemasan, tapi diukur dari segi persepsi konsumen. Seringkali konsumen menilai suatu produk dari berbagai informasi yang kemudian mereka asosiasikan dengan produk tersebut. Informasi ini berasal dari produk itu sendiri (intrinsik) yang terkait dengan karakter fisik produk, misalnya ukuran, rasa, warna, dan aroma. Dari luar produk (ekstrinsik) antara lain harga, kemasan dan iklan. Seringkali konsumen tidak dapat mengabaikan faktor ini dalam menilai produk. Meskipun konsumen seringkali mengatakan bahwa mereka membeli suatu produk karena rasanya enak, namun saat dilakukan tes perbandingan dengan produk lain yang sejenis tanpa merek, mereka tidak dapat membedakan produk yang mereka sukai.

Sementara itu Garvin yang dikutip oleh Mowen dan Minor (2000) mengatakan dimensi dari kualitas produk yaitu kinerja, fitur, reliabilitas, daya tahan, pelayanan, estetika, sesuai dengan spesifikasi, serta kualitas penerimaan.

Sementara itu Iqbal dalam El Janusi (2009) menyebutkan atribut-atribut produk Islam dari bank syariah adalah menghindari unsur riba, hasil investasi dibagi menurut bagi hasil (mudharabah), menghindari unsur ketidak-pastian (gharar), menghindari unsur gambling/judi (maisir), melakukan investasi yang halal, serta melakukan aktivitas sesuai dengan syariah.

\section{Komitmen Agama}

Komitmen adalah suatu keadaan psikologis yang secara global mewakili pengalaman ketergantungan pada suatu hubungan; komitmen meringkas pengalaman ketergantungan sebelumnya dan mengarahkan reaksi pada situasi baru (Barnes, 2003). Komitmen merupakan orientasi jangka panjang dalam suatu hubungan, termasuk keinginan untuk mempertahankan hubungan itu. Bagi bisnis yang menghadapi tingkat persaingan tinggi, hal ini mengimplikasikan bahwa kemampuan perusahaan untuk menciptakan hubungan yang tahan lama dengan pelanggan tidak hanya ditentukan oleh aksi perusahaan itu sendiri, melainkan juga oleh aksi para pesaingnya.

Peppers dan Rogers (Rini, 2007) mengemukakan dua tipe komitmen yang berbeda yaitu calculative dan affective. Calculative commitment berhubungan dengan tipe instrumen dari komitmen, dan sebagai perluasan dari kebutuhan untuk memertahankan hubungan yang disebabkan oleh adanya manfaat ekonomi dan biaya perpindahan (switching cost). Calculative commitment dihasilkan dari analisis ekonomi dari biaya dan manfaat dengan membuat komitmen. Sementara affective commitment timbul karena seseorang memiliki ikatan emosional, bukan karena alasan ekonomi.

Sementara itu, agama memuat segala sesuatu yang terbaik bagi manusia untuk mengolah tujuan-tujuan hidupnya. Agama menyediakan cita-cita kebahagian dan kesejahteraan, moralitas, etika kerja, manajemen keadilan serta apa saja yang dibutuhkan manusia dalam pergaulan dengan sesamanya dan seluruh unsur alam (Achsien, 2000). Komitmen agama adalah menciptakan sebuah tatanan kehidupan yang di dalamnya tidak ada unsur-unsur yang menindas (al-dhâlim) satu pihak pada pihak lain, sekalipun berbeda agama suku maupun jenis kelamin (Mansyur, 2010). Sedangkan El-Janusi (2009) menyebutkan komitmen agama adalah suatu bentuk kepatuhan pada ajaran 
agama. Bagi muslimin, Islam adalah jalan hidup yang mengatur seluruh aspek kehidupan.

Analisis hubungan agama dengan komitmen terhadap etika tidak berhenti pada afiliasi agama. Analisis dilanjutkan dengan komitmen agama agar terjangkau keagamaannya. Dimensi untuk mengukur komitmen agama adalah kunjungan ke tempat ibadah, partisipasi dalam kegiatan keagamaan dan tingkat kepercayaan agama pribadi (Weber dalam Taufik Abdullah, 1989).

\section{Kualitas Layanan}

Kualitas layanan adalah tingkat keunggulan yang diharapkan dan pengendalian atas tingkat keunggulan tersebut untuk memenuhi keinginan pelanggan (Wyckoff dalam Tjiptono, 2004). Kualitas layanan di sini berarti ukuran yang mampu membedakan harapan yang diinginkan pelanggan terhadap pelayanan yang diterima dari perusahaan yang memberikan pelayanan.

Apabila layanan yang diterima atau dirasakan sesuai dengan yang diharapkan, kualitas layanan dipersepsikan baik dan memuaskan. Jika layanan yang diterima melampaui harapan pelanggan, kualitas layanan dipersepsikan sebagai kualitas yang ideal. Sebaliknya jika layanan yang diterima lebih rendah daripada yang diharapkan, kualitas layanan dipersepsikan buruk. Dengan demikian baik tidaknya kualitas layanan tergantung pada kemampuan penyedia layanan dalam memenuhi harapan pelanggannya secara konsisten.

Kualitas harus dimulai dari kebutuhan pelanggan dan berakhir pada persepsi pelanggan. Hal ini berarti bahwa citra kualitas yang baik bukanlah berdasarkan sudut pandang atau persepsi pihak penyedia jasa, melainkan berdasarkan sudut pandang atau persepsi pelanggan. Pelangganlah yang mengonsumsi dan menikmati jasa perusahaan, sehingga merekalah yang seharusnya menentukan kualitasnya.

Gronroos mencoba merumuskan dimensi atau faktor yang dipergunakan konsumen dalam menilai kualitas layanan menggunakan tiga kriteria pokok, yaitu outcome-related, process-related, dan image-related criteria (Tjiptono, 2004). Sementara Parasuraman et. al (1985) mengemukakan faktor-faktor yang digunakan untuk mengukur kualitas layanan meliputi keandalan (reliability), daya tanggap (responsiveness), bukti fisik (tangibility), empati (empathy), dan jaminan (assurance).

\section{Kepercayaan}

Kepercayaan adalah keyakinan bahwa seseorang akan menemukan apa yang diinginkan pada mitra pertukaran. Kepercayaan melibatkan kesediaan seseorang untuk untuk bertingkah laku tertentu karena keyakinan bahwa mitranya akan memberikan apa yang ia harapkan dan suatu harapan yang umumnya dimiliki seseorang bahwa kata, janji atau pernyataan orang lain dapat dipercaya (Barnes, 2003). Ada beberapa elemen penting dari kepercayaan yaitu (1) kepercayaan merupakan perkembangan dari pengalaman dan tindakan di masa lalu; (2) watak yang diharapkan dari mitra seperti dapat dipercaya dan dapat dihandalkan; (3) kepercayaan melibatkan kesediaan untuk 
menempatkan diri dalam risiko; serta (4) kepercayaan melibatkan perasaan aman dan yakin pada diri mitra (Barnes, 2003).

Dari sudut pandang pemasaran, kepercayaan dan keyakinan, seharusnya menjadi komponen fundamental dari strategi pemasaran yang ditujukan untuk mengarah pada penciptaan hubungan pelanggan sejati. Pelanggan harus mampu merasakan bahwa dia dapat mengandalkan perusahaan; bahwa perusahaan dapat dipercaya. Akan tetapi, untuk membangun kepercayaan membutuhkan waktu lama dan hanya dapat berkembang setelah pertemuan yang berulangkali dengan pelanggan. Lebih penting, kepercayaan berkembang setelah seorang individu mengambil risiko dalam berhubungan dengan mitranya. Hal ini menunjukkan bahwa membangun hubungan yang dapat dipercaya akan lebih mungkin terjadi dalam sektor industri tertentu, terutama yang melibatkan pengambilan risiko oleh pelanggan dalam jangka pendek atau membutuhkan obligasi jangka panjang.

\section{Kepuasan Nasabah}

Kepuasan pelanggan sebenarnya merupakan sesuatu yang sulit untuk dirumuskan karena bersifat abstrak. Pencapaian kepuasan dapat merupakan suatu proses yang sederhana maupun rumit. Dalam hal ini peranan individu berpengaruh terhadap kepuasan yang akan dibentuk. Engel (Tjiptono, 2004) kepuasan pelanggan merupakan evaluasi purnabeli di mana alternatif yang dipilih sekurang-kurangnya memberikan hasil (outcome) sama atau melampui harapan pelanggan, sedangkan ketidakpuasan timbul apabila hasil yang diperoleh tidak memenuhi harapan pelanggan. Sedangkan menurut Kotler (Tjiptono, 2004) kepuasan pelanggan adalah tingkat perasaan seseorang setelah membandingkan kinerja (atau hasil) yang ia rasakan dibandingkan dengan harapannya. Pada dasarnya kepuasan atau ketidakpuasan pelanggan merupakan perbedaan antara harapan dan kinerja yang dirasakan.

Tingkat kepuasan pelanggan merupakan suatu hal yang sangat diharapkan oleh pengelola jasa. Dengan diketahuinya tingkat kepuasan pelanggan, pengelola jasa dapat membuat perencanaan bagi kemajuan usahanya di masa yang akan datang.

Pengukuran tingkat kepuasan pelanggan erat hubungannya dengan mutu produk (barang atau jasa). Kotler mengemukakan metode untuk mengukur kepuasan pelanggan (Tjiptono, 2004) yaitu sistem keluhan dan saran pelanggan, Survei kepuasan pelanggan, ghost shopping, dan lost customer analysis.

Untuk memenangkan persaingan, perusahaan harus mampu memberikan kepuasan kepada para pelanggan, misalnya memberikan produk yang bermutu lebih baik, harga lebih murah, penyerahan produk lebih cepat, dan pelayanan yang lebih baik daripada para pesaingnya. Apabila pelayanan yang diterima atau dirasakan sesuai dengan yang diharapkan, kualitas pelayanan dipersepsikan baik dan memuaskan.

\section{METODE PENELITIAN}

Penelitian ini merupakan penelitian yang menjelaskan hubungan kausal antar variabel penelitian, serta melakukan pengujian hipotesis, atau penelitian 
eksplanatori, yang didalamnyaberusaha menemukan hubungan sebab akibat antar variabel yang diteliti. Penelitian ini dilakukan di Kota Ambon pada bulan Juli - September 2017. Populasi penelitian ini adalah nasabah Bank Muamalat Cabang Ambon, yang telah menjadi nasabah sekurang-kurangnya 1 tahun.

Teknik yang digunakan dalam pengambilan sampel dalam penelitian ini adalah accidental sampling, yaitu pengambilan sampel berdasarkan kebetulan, siapa saja yang secara kebetulan bertemu dengan peneliti pada saat pengumpulan data dapat digunakan sebagai responden penelitian.

Data diperoleh dengan menyebarkan kuesioner secara langsung kepada nasabah PT. Muamalat Cabang Ambon yang bersedia menjadi responden. Kuesioner disusun berdasarkan skala Likert dengan rentang alternatif jawaban antara 1 (Sangat Tidak Setuju) sampai dengan 5 (Sangat Setuju). Data yang terkumpul diolah menggunakan SPSS 21.

Teknik analisis yang digunakan dalam penelitian ini adalah analisis regresi berganda, dengan formula :

$$
Y=b 0+b_{1} X_{1}+b_{2} X_{2}+b_{3} X_{3}+b_{4} X_{4}+\varepsilon
$$

di mana :

$$
\begin{array}{ll}
\mathrm{Y} & =\text { Kepuasan Nasabah } \\
\mathrm{X}_{1} & =\text { Atribut Produk Islam } \\
\mathrm{X}_{2} & =\text { Komitmen Agama } \\
\mathrm{X}_{3} & =\text { Kepercayaan } \\
\mathrm{X}_{4} & =\text { Kualitas Layanan } \\
\mathrm{b}_{0} & =\text { Konstanta } \\
\mathrm{b}_{1} \ldots \mathrm{b}_{4} & =\text { Koefisien regresi } \\
\varepsilon & =\text { Nilai residual }
\end{array}
$$

\section{HASIL DAN PEMBAHASAN}

Karakteristik Responden

Responden penelitian ini berjumlah 73 orang nasabah PT Bank Muamalat (Tbk) Cabang Ambon. Hasil tabulasi menunjukan mereka terdiri dari 44 orang $(60,3 \%)$ laki-laki dan 29 orang $(39,7 \%)$ perempuan. Menurut kelompok usia responden penelitian ini yang berusia $<30$ tahun sebanyak 11 orang 15,1\%), antara 31-550 tahun 43 orang (58,9\%), dan $>50$ tahun sebanyak 19 orang $(26,0 \%)$. Selanjutnya responden penelitian ini yang memiliki tingkat pendidikan SMA/Sederajat sebanyak 16 orang $(21,9 \%)$, diploma sebanyak 25 orang $(34,2 \%)$, sarjana sebanyak 27 orang $(37,0 \%)$, dan pascasarjana sebanyak 5 orang $(6,8 \%)$. Sementara itu, responden yang telah menjadi nasabah PT Bank Muamalat (Tbk) Cabang Ambon kurang dari 5 tahun sebanyak 17 orang $(23,3 \%)$, antara 5 sampai dengan 10 tahun sebanyak 38 orang (52,1\%), dan lebih dari 10 tahun sebanyak 18 orang $(24,7 \%)$. Dari jenis pekerjaan, responden yang bekerja sebagai pegawai negeri sipil sebanyak 5 orang $(6,8 \%)$, pegawai swasta sebanyak 10 orang $(13,7 \%)$, wirausahawan sebanyak 40 orang (54,8\%), anggota TNI/Polri sebanyak 7 orang $(9,6 \%)$, serta professional sebanyak 11 orang (15,1\%). Sementara menurut besaran penghasilan per bulan, responden yang memiliki penghasilan < Rp. 5.000.000,- sebanyak 1 orang $(1,4 \%)$, > Rp. 5.000.000,- - Rp. 
10.000.000,- sebanyak 32 orang $(43,8 \%)$ serta > Rp. 10.000.000,- sebanyak 40 orang $54,8 \%)$.

\section{Analisis Regresi Linier Berganda}

Analisis regresi berganda digunakan untuk mengukur besarnya kontribusi atau pengaruh variabel bebas terhadap variabel terikat. Sebelum dilakukan analisis regresi berganda, terlebih dahulu dilakukan pengujian terhadap validitas dan reliabilitas data yang dikumpulkan melalui kuesioner. Hasil pengujian validitas menunjukan tidak semua indikator yang digunakan dalam penelitian ini valid. Terdapat 2 indikator yang tidak valid yaitu X1.1 dan X1.2 dengan nilai koefisien $<0,6$ dan signifikansi $>0,05$ sehingga tidak diikutkan dalam analisis lebih lanjut. Selanjutnya hasil pengujian reliabiitas juga menunjukan semua variabel adalah reliabel untuk digunakan dalam melakukan pengukuran, yang ditunjukan melalui nilai Cronbach Alpha > 0,60.

Ringkasan hasil pengujian persamaan regresi dalam penelitian ini dalam bentuk persamaan regresi berganda disajikan dalam tabel berikut.

Tabel 3. Ringkasan Hasil Regresi

\begin{tabular}{|c|c|c|c|c|c|c|c|}
\hline \multirow{2}{*}{\multicolumn{3}{|c|}{ Model }} & \multicolumn{2}{|c|}{$\begin{array}{l}\text { Unstandardized } \\
\text { Coefficients }\end{array}$} & \multirow{2}{*}{$\begin{array}{c}\text { Standardized } \\
\text { Coefficients } \\
\text { Beta } \\
\end{array}$} & \multirow[b]{2}{*}{$\mathrm{t}$} & \multirow[b]{2}{*}{ Sig. } \\
\hline & & & $\mathrm{B}$ & Std. Error & & & \\
\hline \multirow[t]{9}{*}{1} & (Const & & .379 & .247 & & 1.533 & .130 \\
\hline & Atribu & & .529 & .091 & .486 & 5.819 & .000 \\
\hline & Komit & & .517 & .159 & .146 & 3.255 & .008 \\
\hline & Keper & yaan & .144 & .092 & .179 & 3.570 & .001 \\
\hline & Kualit & & .339 & .060 & .454 & 5.635 & .000 \\
\hline & $\mathrm{R}$ & $=0,897$ & & & & & \\
\hline & $\mathrm{R}^{2}$ & $=0,804$ & & & & & \\
\hline & $F_{\text {hitung }}$ & $=69,692$ & & & & & \\
\hline & Sig & $=0,000$ & & & & & \\
\hline
\end{tabular}

Sumber : Hasil Pengolahan, 2017

Berdasarkan tabel ' di atas, model persamaan yang dihasilkan penelitian ini dalam bentuk persamaan regresi berganda adalah :

$$
Y=0,379+0,529 X_{1}+0,517 X_{2}+0,144 X_{3}+0,339 X_{4}+0,196
$$

Dari hasil persamaan regresi tersebut di atas maka dapat dijelaskan sebagai berikut :

$\mathrm{b}_{0}=0,379$ merupakan nilai konstanta, artinya tanpa adanya atribut produk Islam, koitmen agama, kepercayaan dan kualitas layanan maka kepuasan nasabah PT Bank Muamalat Cabang Ambon adalah sebesar 0,379 atau $37,9 \%$.

$b_{1}=0,529$ menunjukkan apabila persepsi nasabah atas atribut produk Islam yang dtawarkan PT Bank Muamalat Cabang Ambon ditingkatkan, sedangkan faktor-faktor lainnya tetap maka akan memengaruhi kepuasan nasabah sebesar 0,529 atau 52,9\%. 
$\mathrm{b}_{2}=0,517$ menunjukkan persepsi atas komitmen agama dari nasabah PT Bank Muamalat Cabang Ambon ditingkatkan, sedangkan faktor-faktor lainnya tetap maka akan memengaruhi kepuasan nasabah sebesar 0,107 atau $51,7 \%$.

$\mathrm{b}_{3}=0,144$ menunjukkan persepsi atas kepercayaan dari nasabah PT Bank Muamalat Cabang Ambon ditingkatkan, sedangkan faktor-faktor lainnya tetap maka akan memengaruhi kepuasan nasabah sebesar 0,144 atau $14,4 \%$.

$\mathrm{b}_{4}=0,339$ menunjukkan persepsi nasabah atas kualitas layanan PT Bank Muamalat Cabang Ambon ditingkatkan, sedangkan faktor-faktor lainnya tetap maka akan memengaruhi kepuasan nasabah sebesar 0,339 atau $33,9 \%$.

$\varepsilon=0,196$ menunjukan nilai residu atau nilai pengaruh dari variabel lain yang tidak diikutkan dalam penelitian ini.

Nilai $\mathrm{R}=0,897$ atau $89,7 \%$ menunjukan korelasi atribut produk Islam, komiten agama, kepercayaan dan kualitas layanan terhadap kepuasan nasabah PT Bank Muamalat Cabang Ambon, sedangkan nilai koefisien determinasi $\mathrm{R}^{2}=$ 0,804 menunjukan atribut produk Islam, koitmen agama, kepercayaan, dan kepuasan nasabah secara bersama-sama dapat menjelaskan kepuasan nasabah sebesar $80,4 \%$, sedangkan sisanya $19,6 \%$ oleh faktor lain yang tidak ikut diteliti. Hasil ini menunjukan persepsi responden atas atribut produk Islam, komitmen agama, kepercayaan dan kualitas layanan memberikan kontribusi sebesar 80,4\% terhadap pembentukan kepuasan nasabah PT bank Muamalat Cabang Ambon.

\section{Pengujian Hipotesis}

Tabel 1 menunjukan nilai t-hitung variabel atribut produk Islam sebesar 5.819 dengan signifikansi 0,000 sementara nilai t-tabel adalah 1,67 dengan demikian nilai t-hitung $>\mathrm{t}$-tabel, sehingga hipotesis 1 yang diajukan dalam penelitian ini dapat diterima, di mana atribut produk Islam berpengaruh positif dan signifikan terhadap kepuasan nasabah PT Bank Muamalat Cabang Ambon.

Kemudian nilai t-hitung variabel komitmen agama sebesar 3.255 dengan signifikansi 0,008 sementara nilai t-tabel adalah 1,67 dengan demikian nilai thitung $>\mathrm{t}$-tabel, sehingga hipotesis 2 yang diajukan dalam penelitian ini dapat diterima, di mana komitmen agama berpengaruh positif dan signifikan terhadap kepuasan nasabah PT Bank Muamalat Cabang Ambon.

Selanjutnya nilai t-hitung variabel kepercayaan sebesar 3.570 dengan signifikansi 0,001 sementara nilai t-tabel adalah 1,67 dengan demikian nilai thitung $>\mathrm{t}$-tabel, sehingga hipotesis 3 yang diajukan dalam penelitian ini dapat diterima, di mana kepercayaan berpengaruh positif dan signifikan terhadap kepuasan nasabah PT Bank Muamalat Cabang Ambon.

Sementara nilai t-hitung variabel kualitas layanan sebesar 5.635 dengan signifikansi 0,000 sementara nilai t-tabel adalah 1,67 dengan demikian nilai thitung $>\mathrm{t}$-tabel, sehingga hipotesis 4 yang diajukan dalam penelitian ini dapat diterima, di mana kualitas layanan berpengaruh positif dan signifikan terhadap kepuasan nasabah PT Bank Muamalat Cabang Ambon. 
Tabel 1 juga menunjukan nilai F-hitung sebesar 6,692 dengan signifikansi 0,000 sementara nilai F-tabel sebesar 2,34 menunjukan pengaruh simultan dari variabel atribut produk Islam, komitmen agama, kepercayaan dan kualitas layanan terhadap kepuasan nasabah PT Bank Muamalat Cabang Ambon. Dengan demikian hipotesis 5 yang diajukan dalam penelitian ini dapat diterima, di mana secara bersama-sama atribut produk Islam, komitmen agama, kepercayaan dan kualitas layanan berpengaruh positif dan signifikan terhadap kepuasan nasabah PT Bank Muamalat Cabang Ambon.

\section{Pembahasan}

Hasil penelitian ini menunjukan atribut produk Islam yang ditawarkan oleh PT Bank Muamalat Cabang Ambon memiliki pengaruh yang positif dan signifikan terhadap kepuasan nasabah. Hal ini menunjukan pentingnya atribut produk yang berlandaskan Islam untuk ditawarkan ke pasar. Konsumen yang memiliki persepsi yang positif terhadap atribut produk perbankan syariah yang sesuai ajaran Islam akan cenderung merasa puas ketika menjadi nasabah bank tersebut. Demikian juga komitmen agama memiliki pengaruh yang positif dan signifikan terhadap kepuasan nasabah. Artinya nasabah dengan komitmen agama yang kuat cenderung memiliki kepuasan menjadi nasabah bank syariah. Selanjutnya hasil penelitian menunjukan kualitas layanan yang diberikan oleh PT Bank Muamalat Cabang Ambon memiliki pengaruh yang positif dan signifikan terhadap kepuasan nasabah. Hasil penelitian ini sejalan dengan penelitian Daulay (2013) yang menemukan adanya pengaruh yang positif dan signifikan dari atribut produk produk yang islami terhadap minat menabung pada Bank BNI Syariah di Medan. Demikian pula sejalan dengan hasil penelitian Cahyani, dkk. (2013) dan Hastuti (2013). Karena itu, kebijakan dan strategi yang dikembangkan oleh perbankan syariah dlam usaha untuk meningkatkan kepuasan nasabahnya, hendaknya tetap memberi perhatian pada produk yang ditawarkan, faktor spiritualitas nasabah, dan kualitas layanan yang diberikan oleh pihak perbankan.

\section{PENUTUP}

\section{Kesimpulan}

Dari hasil analisis dan pembahasan yang dilakukan, kesimpulan yang dapat diambil sehubungan dengan penelitian ini yaitu :

1. Atribut produk Islam memiliki pengaruh yang positif dan signifikan terhadap kepuasan nasabah PT Bank Muamalat Cabang Ambon, di mana semakin tinggi persepsi pelanggan atas atribut produk Islam yang ditawarkan maka kepuasan nasabah juga makin meningkat.

2. Komitmen agama memiliki pengaruh yang positif dan signifikan terhadap kepuasan nasabah PT Bank Muamalat Cabang Ambon, di mana semakin tinggi komitmen pelanggan maka kepuasan nasabah juga makin meningkat.

3. Kepercayaan memiliki pengaruh yang positif dan signifikan terhadap kepuasan nasabah PT Bank Muamalat Cabang Ambon, di mana semakin tinggi persepsi kepercayaan pelanggan terhadap PT Bank Muamalat maka kepuasan nasabah juga makin meningkat. 
4. Kualitas layanan memiliki pengaruh yang positif dan signifikan terhadap kepuasan nasabah PT Bank Muamalat Cabang Ambon, di mana semakin tinggi persepsi pelanggan atas kualitas layanan yang dirasakan maka kepuasan nasabah juga makin meningkat.

5. Atribut produk Islam, komitmen agama, kepercayaan dan kualitas layanan secara simultan memiliki pengaruh yang positif dan signifikan terhadap kepuasan nasabah PT Bank Muamalat Cabang Ambon, di mana semakin tinggi persepsi pelanggan atas atribut produk Islam yang ditawarkan, komitmen agama, kepercayaan, dan kualitas layanan maka kepuasan nasabah juga makin meningkat.

Saran

Dalam upaya untuk meningkatkan kepuasan nasabah maka saran yang dapat dikemukakan adalah sebagai berikut:

1. Dalam rangka meningkatkan kepuasan nasabah, hendaknya pihak manajemen PT Bank Muamalat Cabang Ambon lebih memberi perhatian pada faktor-faktor yang bercirikan agama Islam dalam promosi produknya kepada konsumen potensial.

2. Penelitian lebih lanjut perlu dilakukan di masa mendatang dengan memasukan lebih banyak variabel yang terkait dengan perilaku nasabah dalam hubungannya dengan perbankan syariah.

\section{DAFTAR PUSTAKA}

Achsien, Iggi H. 2000. Investasi Syariah di Pasar Modal. Jakarta: Gramedia Pustaka Utama

Angiopora, Marinus P. 2002. Dasar-dasar Pemasaran. Jakarta: Raja Grafindo Persada.

Antonio, Muhammad Syafii. 2001. Bank Syariah dari Teori ke Praktek. Jakarta: Gema Insani.

Assauri, Sofyan. 1998. Manajemen Pemasaran : Dasar, Konsep, dan Strategi. Jakarta: Rajawali,

Barat, Somjit and Spillan, John E. 2012. An Exploratory Study of Customer Satisfaction in a Community Bank, International Journal of Customer Relationship Marketing and Management, Vol. 3, No. 3, July-September, 1532

Barnes, James G. 2003. Rahasia Manajemen Hubungan Pelanggan. Yogyakarta: Penerbit Andi

Cahyani, Asih Fitri, Saryadi \& Sendhang Nurseto. 2013. Pengaruh Persepsi

Bunga Bank dan Kualitas Pelayanan Terhadap Minat Menabung Pada

Bank BNI Syariah di Kota Semarang, Diponegoro Journal of Social and

Politic, Tahun 2013, 1-8

Churchill, Gilbert A. Jr. 1982. An Investigation into the Determinants of

Customer Satisfaction, Journal of Marketing Research, Vol. 19, No. 4, Nov, 491-504

Damodar, Gujarati. 2003. Ekonometrika Dasar. Jakarta: Erlangga 
Daulay, Raihanah. 2010. Analisis Pelayanan dan Bagi Hasil Terhadap Keputusan Menabung Nasabah Pada Bank Syariah di Kota Medan, Jurnal Manajemen \& Bisnis, Vol 10 No. 01 April, 1-12

El Janusi, Rahman. 2009. Pengaruh Atribut Produk Islam, Komitmen Agama, Kualitas Jasa Dan Kepercayaan Terhadap Kepuasan Dan Loyalitas Nasabah Bank Syari' ah (Pada Bank Muamalat Kota Semarang)". Annual Conference on Islamic Studies (ACIS). 2-5 November 2009. Surakarta.

Ghozali, Imam. 2001. Aplikasi Analisis Multivariate dengan Program SPSS. Semarang: Badan Penerbit Universitas Diponegoro

Hastuti. Tuti. 2013. Kualitas Pelayanan Dan Pola Bagi Hasil Terhadap Kepuasan Nasabah Penyimpan Pada Bank Syariah, Jurnal Manajemen Dan Akuntansi, Volume 2, Nomor 1, April 2013, 58-69

Karim, Adiwarman A. 2010. Bank Islam; Analisis Fiqih dan Keuangan. Jakarta: Raja Grafindo Persada

Kotler, Philip dan Gary Amstrong. 2001. Prinsip-prinsip Pemasaran. Jakarta: Erlangga

Kotler, Philip. 2001. Manajemen Pemasaran: Analisis, Perencanaan, Implementasi, dan Pengawasan. Jakarta: Erlangga

Kuncoro, Mudrajad dan Suhardjono. 2002. Manajemen Perbankan; Teori dan Aplikasi. Yogyakarta: BPFE-Yogyakarta

Lupiyoadi, Rambat. 2001. Manajemen Pemasaran Jasa: Teori dan Praktek. Jakarta: Salemba Empat

Machmud, Amir dan Rukmana. 2010. Bank Syariah; Teori, Kebijakan dan Studi Empiris di Indonesia. Jakarta: Erlangga

Mowen, John C. dan Michael Minor. 2000. Perilaku Konsumen. Jakarta: Erlangga,

Muhammad. 2002. Kebijakan Fiskal dan Moneter dalam Ekonomi Islam. Jakarta : Salemba Empat

Peter, J. Paul dan Jerry C. Olson. 1999. Consumer Behavior; Perilaku Konsumen dan Strategi Pemasaran. Jakarta: Erlangga

Pradiansyah, Arvan. 2009. Peranan Kepemimpinan dalam Membangun Kepercayaan di Tempat Kerja, Majalah Usahawan, No. 19 th. XXVIII September.

Rini, Endang Sulistya. 2007. Pengaruh Economic Content, Resource Content, dan Social Content terhadap Kepercayaan, Kepuasan dan Komitmen serta Relationship Intention Debitur Bank Sumut di Sumatera Utara". Disertasi. Program Pascasarjana Universitas Airlangga Surabaya

Saleky, Saul Ronald Jacob, Dian Utami Sutiksno, Aldina Shiratina, 2014, The Effect of Service Quality on Customer Satisfaction of The Manise Hotel in Ambon, Indonesia, Proceeding of $2^{\text {nd }}$ GARCOMBS

Saleky, Saul Ronald Jacob, Wendy Souisa, Wylda Olivia Kowey, dan Herlina Syarifuddin. 2016. The Association of Service Quality, Price of Service and Brand Equity on Customer Satisfaction and Retention of Star-Hotel Guests in Ambon, Maluku Province, in Bendesa, I.K. G., Meydianawathi, L.G., Handra, Hefrizal., Hartono, Djoni., Priyarsono, D.S., Resosudarmo, Budi 
P., and Yusuf, Arif A., 2016. Tourism and Sustainable Development in Indonesia, IRSA Serial Book No. 14

Saleky, Saul Ronald Jacob, Wendy Souisa, Wylda Olivia Kowey, Herlina Syarifuddin. 2015. Contribution of Service Quality, Price of Service and Brand Equity on Customer Satisfaction and Retention of Star Hotel Users in Ambon Town, Proceeding 5th IRSA Institute Conference

Salhuteru , Andrie Ch. 2017. Pengaruh Kualitas Layanan Dan Kepuasan Pasien Terhadap Words of Mouth Pada Rumah Sakit Umum Daerah Dr. M.

Haulussy Ambon, Jurnal Manajemen Ide dan inspirasi, Vo. 4, No. 1, Juni, 84-94

Schiffman, Leon G. dan Leslie Lazar Kanuk. 2000. Consumer Behavior. New Jersey : Prentice Hall

Siamat, Dahlan. 2004. Manajemen Lembaga Keuangan. Jakarta: Lembaga Penerbit Fakultas Ekonomi Universitas Indonesia

Singh, Jaspal and Kaur, Gagandeep, 2011, Customer Satisfaction and universal banks : an empirical study, International Journal of Customer and Management, Vol. 21, No. 4, 327-348

Stanton, William J. et.al. 14. Fundamentals of Marketing. New Jersey: McGrawHill

Sugiyono. 2006. Metode Penelitian Bisnis. Bandung: Alfabeta

Suhartanto, Dwi. 2001. Kepuasan Pelanggan: Pengaruhnya Terhadap Perilaku Konsumen di Industri Perhotelan. Majalah Usahawan No. 07 Thn XXX Juli Syariati, A. The Effect Of Islamic Comercial Banks'health And Their Cost Of Fund Upon Its Financing In Indonesia over 2005-2009.

Syariati, A., \& Syariati, N. E. (2012). Islamic Bank as Bank of Ethics. In Proceeding of Annual South East Asian International Seminar.

Tjiptono, Fandy. 2004. Manajemen Jasa. Yogyakarta: Andi 


\title{
Penanggung Jawab \\ Ambo Asse
}

\section{Ketua/}

M. Wahyuddin Abdullah

\author{
Dewan Editor \\ Alim Syariati \\ Rusdi Prayoga \\ Andi Mulia \\ Rusnawati
}

\author{
Mitra Bestari/Reviewer \\ Ambo Asse (UIN Alauddin Makassar), \\ Firman Menne (Universitas Bosowa Makassar) \\ Suwandi Ng (Universitas Atma Jaya Makassar), \\ Agus Salim (ISEI Sul-Sel), \\ Rika Dwi Ayu Parmitasari (UIN Alauddin Makassar), \\ Ahmad Efendi (UIN Alauddin Makassar), \\ Awaluddin (UIN Alauddin Makassar), \\ Okta Nofri (UIN Alauddin Makassar), \\ Eka Suhartini (UIN Alauddin Makassar), \\ Akil Rahman (UIN Alauddin Makassar),
}

\author{
Sekretaris Penyunting \\ Rusmawandi Rara \\ Nurhikma Hawabaja \\ Roshani
}

\author{
JURNAL MINDS \\ Pusat Dokumentasi dan Publikasi IImiah \\ Jurusan Manajemen Fakultas Ekonomi dan Bisnis Islam UIN Alauddin \\ JI. Sultan Alauddin No. 33 Samata-Gowa Sul-Sel -- INDONESIA \\ Telp/HP. 081355774774, 081241840208, Fax. (0411) 8221400 \\ Website OJS: http://journal.uin-alauddin.ac.id/index.php/minds \\ Email: minds@uin-alauddin.ac.id
}




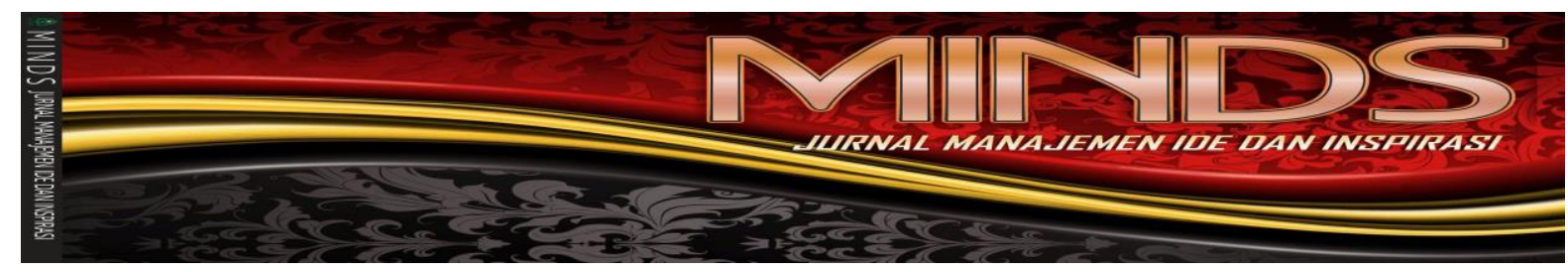

\section{KRITERIA TULISAN}

1. Panjang tulisan minimal 10 halaman dan maksimal 15 halaman

2. Menggunakan huruf Book Antiqua, font 12 , spasi 1, margin atas-bawah $3 \mathrm{~cm}$, kiri-kanan $2.54 \mathrm{~cm}$.

3. Tulisan dapat berupa hasil penelitian kuantitatif (diutamakan), penelitian kualitatitif, dan kajian teoritis dalam bidang Manajemen dengan penguatan pada integrasi keislaman.

4. Identitas penulis meliputi: nama penulis tanpa gelar, nama dan alamat afiliasi, dan alamat email penulis (contoh Alim Syariati, Fakultas Ekonomi dan Bisnis Islam UIN Alauddin, JI. HM. Yasin Limpo, NO. 63 Samata-Gowa, alim.syariati@uin-alauddin.ac.id).

5. Komposisi tulisan harus mengikuti pola berikut:

a. Judul

b. Abstrak (bahasa Indonesia dan bahasa Inggris) maksimal 150 kata dan kata kunci 3-5 kata

c. Pendahuluan (Yang didalamnya menyinggung mengenai masalah penelitian)

d. Tinjauan teoritis

e. Metode penelitian

f. Pembahasan

g. Penutup

h. Daftar pustaka

Buku: Hartono, Jogiyanto, 2004. Metodologi Penelitian Bisnis: Salah Kaprah dan pengalaman-pengalaman. Edisi 2004/2005. BPFE, Yogyakarta

Jurnal: Barney, Jay B. 1995. Looking Inside Competitive Advantage. Academy of Management, pp. 49-61

Penelitian Tidak Publikasi: Minimal sumber referensi berasal dari disertasi S3 (tapi tidak dianjurkan), dengan mengikuti format di atas

6. Menggunakan Innote

7. Waktu penting dalam penerbitan Jurnal berkala IImiah Minds, yaitu bulan Maret- Mei untuk terbitan pertama tahun berjalan, dan Oktober-November untuk terbitan kedua tahun berjalan melalui online journal system (OJS) yang bisa diakses melalui laman http://journal.uin-alauddin.ac.id/index.php/minds. Pertanyaan terkait jurnal Minds bisa disampaikan melalui email: minds@uin-alauddin.ac.id atau alim.syariati@uinalauddin.ac.id 